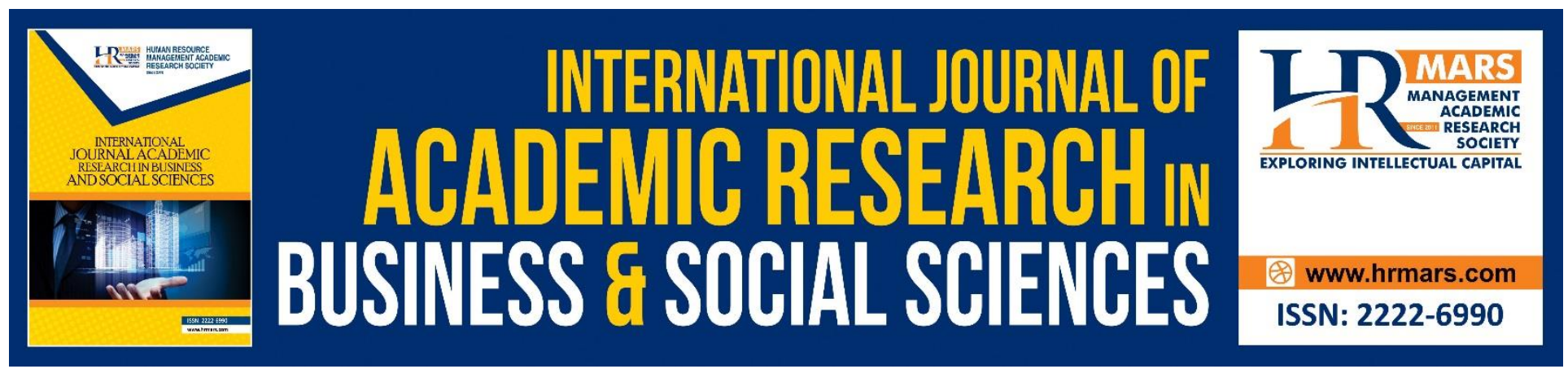

\title{
Interpersonal Attraction Traits on Facebook
}

\author{
Jusang Bolong, Sri Azra Attan
}

To Link this Article: http://dx.doi.org/10.6007/IJARBSS/v11-i15/10648

DOI:10.6007/IJARBSS/v11-i15/10648

Received: 17 May 2021, Revised: 22 June 2021, Accepted: 07 July 2021

Published Online: 29 July 2021

In-Text Citation: (Bolong \& Attan, 2021)

To Cite this Article: Bolong, J., \& Attan, S. A. (2021). Interpersonal Attraction Traits on Facebook. International Journal of Academic Research in Business and Social Sciences, 11(15), 214-228.

Copyright: (C) 2021 The Author(s)

Published by Human Resource Management Academic Research Society (www.hrmars.com)

This article is published under the Creative Commons Attribution (CC BY 4.0) license. Anyone may reproduce, distribute, translate and create derivative works of this article (for both commercial and non-commercial purposes), subject to full attribution to the original publication and authors. The full terms of this license may be seen

at: http://creativecommons.org/licences/by/4.0/legalcode

Special Issue: Empowering Youth and Community Wellbeing for Sustainable Development, 2021, Pg. 214 - 228 http://hrmars.com/index.php/pages/detail/IJARBSS JOURNAL HOMEPAGE

Full Terms \& Conditions of access and use can be found at http://hrmars.com/index.php/pages/detail/publication-ethics 


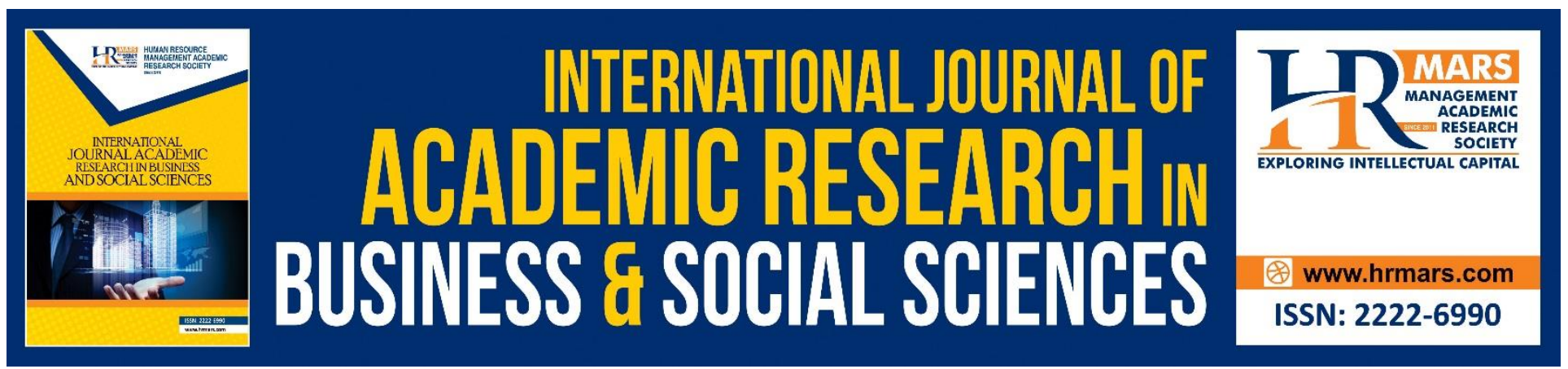

\title{
Interpersonal Attraction Traits on Facebook
}

\author{
Jusang Bolong ${ }^{1,2}$, Sri Azra Attan² \\ ${ }^{1}$ Institute for Social Science Studies (IPSAS), Universiti Putra Malaysia, 43400 UPM Serdang, \\ Selangor, Malaysia, ${ }^{2}$ Faculty of Modern Languages and Communication, Universiti Putra Malaysia, \\ 43400 UPM Serdang, Selangor, Malaysia \\ Email: jusang@upm.edu.my
}

\begin{abstract}
Many are using these social media nowadays to enhance the interpersonal relationships, regardless of an existing or a new friend. Facebook users are engaging in numerous ways to initiate or maintain interpersonal relationships, such as increasing the frequency of interactions, improving the quality of communications, and utilizing self-disclosure approaches through displaying interpersonal attraction traits, but do they agree on whether or not to display the traits of interpersonal attraction on Facebook? This study to identify the interpersonal attraction traits, highlighted by Facebook users in order to improve their interaction network through mediated-communication. By using a purposive sampling procedure, a total of 402 respondents who use Facebook, which was invited to fill out a questionnaire on a Google Form. Facebook users agreed that interpersonal attraction traits such as physical attraction, social attraction, extraversion, and popularity, should be highlighted; however, they have to be neutral in highlighting the traits. The findings of this study contribute towards advancing knowledge on reducing uncertainty due to interpersonal attraction traits and to meet the needs for creating a demanding community that facilitate the interactions of people with collective interests for social networking enhancement.
\end{abstract}

Keywords: Interpersonal Attraction, Physical Attraction, Social Attraction, Popularity, Extraversion.

\section{Introduction}

The presence of New Communication Technology changes how people relate to one another, and Computer-Mediated Communication is yet to reinstate the conventional medium of communication as an active communication channel. Such activity on Social Networking Sites (SNS) is replacing Faceto-Face social interactions and reaching people who have undergone an individual social capital through various platforms of social media, e.g., Facebook, YouTube, Instagram, Tumblr, and Twitter. Many are using these social media nowadays to build, maintain, and enhance interpersonal relationships, regardless of an existing or a new friend.

An interpersonal relationship is the personal sentimental bond between people, e.g., friendship, affection, or respect, which implies the interdependence between another and tends to share their judgments and beliefs (Kelley, 2013). This kind of relationship is centered on emotional support, 
which includes mutual interest, e.g., enjoying the same food and interested in a similar topic of discussion (Attan, 2011) by having social interaction amongst them. Social media users are engaging in numerous ways to initiate or maintain interpersonal relationships, such as increasing the frequency of interactions, improving the quality of communications, and utilizing self-disclosure approaches through interpersonal attraction traits contribution.

However, in social psychology, the interpersonal attraction traits are the intention of a person to have admiration and warm approval towards someone else, which is related to a person admires, adores, or hates another person that they knew in their life (Unal and Kobak, 2011). Without interpersonal attraction traits, there would be no love for a family member, romantic partner, or friend. Thus, without this energizing effect of emotions, life would be a colorless painting (Bailey, 2007), as interpersonal attraction traits are essential to developing a relationship in social media like Facebook. The reason is those interpersonal attraction traits related to the desire that moves two or more persons to be together by developing a lifelong relationship, which primarily relates to the occurrence of thought regarding what they keen and fond of until they started to be loving to each other.

This study describes the interpersonal attraction traits highlighted by Facebook users in order to improve their interaction network through mediated-communication.

\section{Interpersonal Attraction Traits amongst Facebook Users}

Nowadays, social media usage, including Facebook, has increased in the region and is paving the way for enduring changes in all spheres of public and private life (Koshy, 2013). Individuals use Facebook for various purposes, e.g., communication, learning, work-related activities, entertainment, and socialization. Four interpersonal attraction traits have been discussed in this study, which was influencing Facebook usage, namely physical attraction, social attraction, extraversion, and popularity.

Firstly, physical attraction refers to which users believe that another user is visually pleasing by looking at the physical attributes (McCroskey et al., 2006). For instance, women looking for men with broad shoulders and a strong jawline to show their masculinity and strength. Meanwhile, men look for women with small waists and broad hips to show that they will be able to take care of children (Barelds and Dijkstra, 2009). For another instance, women tended to take and display photographs portraying themselves in a relatively low physical position to emphasize youthfulness and attractiveness. In contrast, men were more likely to take and display photographs portraying themselves in a relatively high physical position to highlight their physical size and dominance (Makhanova et al., 2017).

As this study is focusing on online interaction, physical attraction refers to the self-photos posted by Facebook users on their timeline, which finds appealing to other users. Since the photo is the central component in representing identity, Facebook users were displaying themselves and tagging others through photos updates on Facebook with the intention of self-introducing and presenting the user's identity in the social network (Mendelson and Papacharissi, 2010). Thus, Facebook users always have the intention to post photo updates, especially of the attractive versions of themselves online (Ong et al., 2011). 
Physical attraction is measured using an instrument from the Interpersonal Attraction Scale (IAS) by McCroskey and McCain (1974). Initially, the IAS response set was using a five-point Likert scale, which ranges from 1 for strongly disagree to 5 for strongly agree. Within the context of this study, it was not altered, implemented from the original scale to maintain the scaling slope, which takes less than three minutes to complete all the questions for this variable. Four physical attraction's items are utilizing a five-point Likert scale of ordinal data. The Cronbach's (1951) alpha reliability for the IAS response set is ranged from the lower 0.70 s to the upper 0.90 s in most of the previous studies.

Secondly, social interaction is defined as a social attraction in which existing partners seize the past, present, and future partners as attractive, based on their capability to deliver and access social compatibility (Harris et al. 2003). According to Simpson and Harris (1994), social attraction is a stimulating state wherein an individual is liable to deliberate, belief, sense, and perform constructively towards another person. People are socially attracted to individuals who have stable interaction patterns (Montoya et al. 2008). Thus, social attraction is the desire of one to socialize with someone else whom they are attracted to. For example, people can be attracted to friends of the opposite gender, which they can communicate and spend time for the rest of their life. Hence, social attraction is essential in maintaining a long-lasting relationship between others.

Social attraction is the power, strength, and determination, which encourage an individual to develop their social network with the possibility to expand the social network to a more prominent association within their community (Blau, 1964). Jamerson (2009) suggested that people tend to view others as more attractive if they have a positive interaction with them. With this relaxing interaction, they should be able to get along really well. The more comfortable one gets, the more attracted one will become. From the view of social attraction, someone who is being targeted is pleasurable to be together, befitted to be a friend, and suitable to be in the surrounding of the present group of friends (McCroskey et al., 2006).

Social attraction is also measured using an instrument from IAS constructed by McCroskey and McCain (1974), which uses a five-point Likert scale, ranging from 1 for strongly disagree to 5 for strongly agree. Due to the context of this study, it was not adjusted, implemented from the original scale to maintain the scaling slope, which takes less than three minutes to complete all the questions for this variable. The reliability of Cronbach's (1951) alpha values for the IAS have ranged from the lower 0.70 s to the upper 0.90 s in most of the previous studies.

Thirdly, extraversion is a personality trait in which individuals tend to enjoy being around people, and socialization is a positive way for them to be more outgoing and friendlier. Extraversion is described by positive emotionality, sociability, and dynamic behavior (Naragon-Gaine et al., 2009). It is frequently correlated with life happiness development and depression relief (Andrews et al. 2010). A higher level of extraversion is preventing the occurrence of more significant depression (Simoncic et al. 2014), considering that it promotes the functionality of social support (Hall and Pennington, 2013) through Facebook mainly.

A highly extraverted person is those who use Facebook regularly (Moore and McElroy, 2012) that tend to present the most promising image possible to others (Simoncic et al., 2014). Thus, Facebook users who are high in extraversion interact more with friends through comments, likes, and shares; 
and often post the useful content, including status updates and photos on their timeline (Amichai and Vinitzky, 2010). On the contrary, individuals reporting low extraversion disclose less on Facebook. Usually, they post more negative content (Chen and Marcus, 2012), which may lower their benefits of social networking as well as lower their self-esteem (Forest and Wood, 2012).

The Eysenck Personality Questionnaire-Revised (EPQR) response set by Eysenck and Eysenck (1994) is using a five-point Likert scale ranging from 1 for strongly disagree to 5 for strongly agree. Within the context of this study, it was not modified, applied from the original scale to maintain the scale slop, which takes less than three minutes to complete all the questions for this variable. The EPQR is known in measuring extraversion with the average of Cronbach's (1951) alpha values is above 0.8 for each item around the world; such as England, Canada, United States of America, and Australia (Francis et al. 1992), which ranged from the lower 0.70s to the upper 0.90s in the most of previous studies.

Lastly, popularity is a dimension of attractiveness (Papadopoulos et al. 2012) with various meanings, significances, and interpretations. For some, popularity is interpreted as widely liked or being wellliked by peers (Zywica and Danowski, 2008). Others see it as being socially dominant (Rawlings et al. 2017), and some define popularity as accepted by one's peer group members (Gil et al. 2017).

As popularity plays a significant role in mediated-communications (Utz et al. 2012), the approach of defining popularity on Facebook is not merely on being liked by others, but by the attribution of profile users; e.g., the length of timeline on Facebook (Zywica and Danowski, 2008). Besides, several friends, comments, likes, and shares would be an indicator of being popular on Facebook (De Vries et al., 2012). For example, the index of being popular on Facebook based on the average number of likes per post that is more than 1500, the average number of comments per post is 123, and the average number of shares per post is 29 (Bonson and Ratkai, 2013). As stated, the popularity of Facebook users is indicated by the network size, which rendering on the number of Facebook friends (Weijs et al., 2017). However, the maximum number of friends allowed on Facebook is limited to 5000 friends only (Ekwok, 2017).

Initially, all the popularity items on Facebook Popularity Scale (FPS) by Zywica and Danowski (2008) were using a five-point Likert-type response with the closed-ended questions. The answer choices were ranging from 1 for very unpopular, 2 for unpopular, 3 for neutral, 4 for popular, and 5 for very popular. The five-point scale was not amended, utilized from the initial scale to maintain the scaling slope, except the scale description was changed to give more understanding to the respondents. According to Zywica and Danowski (2008), all FPS's items were checked for reliability by computing the Cronbach's (1951) alpha values, and the overall reliability for Facebook popularity had a coefficient of 0.78 and ranged from the lower 0.70 s to the upper $0.80 \mathrm{~s}$ in the most of previous studies.

\section{Methodology}

The data collection for this study was executed through a quantitative approach by using a surveydevelopment website, specifically http://bit.ly/2w4QXEd. The users of Facebook were chosen as the primary target population since Facebook is the world's largest and most popular online Social Networking Sites (SNS) (Mohammadi et al., 2020). 
A non-probability sampling technique was implemented to generate a sample size for this study. It is difficult to identify the population in this study due to the rapid growth of New Communication Technology. Thus, this study was using a purposive sampling procedure. This procedure includes asking people who have contributed to a survey to recommend other people that they assume are attached to the research and would be willing to take part in the survey. Later, the sampling carried on until the required number of responses is achieved.

Within this study context, the relevant Facebook feature in structuring the snowballing procedure is a Facebook group. Thus, a researcher created the Facebook group based on specific interests, which includes the attraction to one specific local friend in the first year of involvement on Facebook, based on the initial relationship period is between 1-3 years (Baumeister and Vohs, 2007). Then, a snowballing procedure was initiated by gathering respondents to one Facebook group via links to selected Facebook friends. Since the group administrator has access to control the content and the membership of the group, the administrator then progressively transmitted a message to up until the maximum of 5,000 group members. A total of 503 questionnaires were distributed through online, with only 402 respondents returned the questionnaire.

\section{Findings}

\section{Physical Attraction}

Based on Table 1, more than half $(57.71 \%)$ of the respondents strongly disagreed that physically attractive user was repulsive to them $(M=4.34)$. This discovery signified that physically attractive user always has the persona to attract other Facebook users (Halpern et al. 2017). The result also stated that almost half $(47.7 \%)$ of them strongly disagreed that a physically attractive user was somewhat ugly $(M=4.26)$. This figure indicated that physically attractive user is frequently associated with a beautiful woman and handsome man (Elmer and Houran, 2019). Besides, $42.04 \%$ of the respondents strongly disagreed that physically attractive user is wearing the clothes that are not becoming $(M=4.13)$ and that the physically attractive user is not very good looking $(M=3.95)$. Since it was a reverse coded item, the highest mean of physical attraction stated that the physically attractive user is very good looking. This result coincides with Jin's (2010) finding that physically attractive user is evaluated more positively in terms of personality traits; such as attractive, classy, elegant, sexy, cute, and pretty 
INTERNATIONAL JOURNAL OF ACADEMIC RESEARCH IN BUSINESS AND SOCIAL SCIENCES

Vol. 11, No. 15, Empowering Youth and Community Wellbeing for Sustainable Development, 2021, E-ISSN: 2222-6990 @ 2020 HRMARS

Table 1: Distribution of Facebook users by Physical Attraction items ( $N=402)$

\begin{tabular}{|c|c|c|c|c|c|c|c|c|}
\hline \multirow{2}{*}{$\begin{array}{l}\text { No } \\
\text {. }\end{array}$} & \multirow{2}{*}{ Items } & \multicolumn{5}{|c|}{ Percentage (Frequency) } & \multirow{2}{*}{ M } & \multirow{2}{*}{ SD } \\
\hline & & 1 & 2 & 3 & 4 & 5 & & \\
\hline \multirow{2}{*}{1.} & Based on his/her photos/videos on & 57.71 & 21.14 & 18.41 & 2.74 & 0.00 & 4.3 & 0.8 \\
\hline & Facebook, he/she is repulsive to me. & $(232)$ & $(85)$ & $(74)$ & (11) & (0) & 4 & 7 \\
\hline \multirow{2}{*}{2.} & Based on his/her photos/videos on & 47.26 & 31.35 & 21.39 & 0.00 & 0.00 & 4.2 & 0.7 \\
\hline & Facebook, he/she is somewhat ugly. & $(190)$ & $(126)$ & $(86)$ & (0) & (0) & 6 & 9 \\
\hline \multirow[b]{2}{*}{3.} & Based on his/her photos/videos on & 42.04 & 34.33 & 18.16 & 5.47 & 0.00 & 4.1 & 0.8 \\
\hline & $\begin{array}{l}\text { Facebook, the clothes he/she wears } \\
\text { are not becoming. }\end{array}$ & $(169)$ & $(138)$ & $(73)$ & $(22)$ & (0) & 3 & 9 \\
\hline \multirow{4}{*}{4.} & Based on his/her photos/videos on & 42.04 & 19.40 & 32.83 & 2.74 & 2.99 & 3.9 & 1.0 \\
\hline & $\begin{array}{l}\text { Facebook, he/she is not very good } \\
\text { looking. }\end{array}$ & (169) & (78) & (132) & (11) & (12) & 5 & 6 \\
\hline & & & & & \multirow{2}{*}{\multicolumn{2}{|c|}{ Overall }} & 4.1 & 0.9 \\
\hline & & & & & & & 7 & 0 \\
\hline
\end{tabular}

* Note: 1=Strongly Disagree, 2=Disagree, 3=Neutral, 4=Agree, 5=Strongly Agree (All items are reverse coded)

Furthermore, this finding also verified that physical attraction on Facebook is determined through photos and videos, as suggested by Kleemans et al (2018) that photos and videos are both a straightforward form of online self-presentation in order to convey the physical attractiveness amongst online users. The discovery shows that several characteristics of physical attraction trigger an individual to be attracted to another user, e.g., through photos and videos shared on Facebook. This finding is related to Cabral's (2011) study, which stated that users are presenting themselves online through different actions, e.g., frequently uploading photos and videos to represent their physical attraction to other users, e.g., facial expression through pleasing smiles, beautiful eyes, or trendy hairstyle.

\section{Social Attraction}

In terms of social attraction, most of the respondents (41.28\%) agreed that they feel like they know personally the socially attractive user $(M=3.38)$. Almost a quarter $(29.35 \%)$ of the respondent agreed that sometimes they wish to be more like the socially attractive user ( $M=3.35)$, whereas $27.61 \%$ of them strongly agreed that they would like to have a friendly chat with a socially attractive user $(M=3.73)$. According to Table 2 , the highest mean of social attraction $(M=3.73)$ stated that they would like to have a friendly chat with the socially attractive user based on his/her social interaction via comments on Facebook. This result signified that socially attractive user is more appealing to other Facebook users through emotional closeness as they need to intermingle more through social interaction in order for being socially attracted (Kunnanatt, 2004). This finding discovered that social attraction on Facebook could be ascertained through social interaction via comments on Facebook. This assertion is, as advocated by Mantymaki and Islam (2016), that people use SNSs, such as Facebook, for social interaction and communication, by replying messages and posting comments on a preferred Facebook wall (Pempek et al. 2009 ). In other words, the frequency of commenting on the user's wall whether, on status updates, photos or videos, has become a modus operandi for a socially attractive user to convey themselves on Facebook (Wang et al. 2012). This outcome is similar 
INTERNATIONAL JOURNAL OF ACADEMIC RESEARCH IN BUSINESS AND SOCIAL SCIENCES

Vol. 11, No. 15, Empowering Youth and Community Wellbeing for Sustainable Development, 2021, E-ISSN: 2222-6990 @ 2020 HRMARS

to Vittengl and Holt (2000) 's that people are more likely to comment on other's Facebook profile, only to whom they feel socially attracted, for the reason that they are more pleasant to be with. Thus, this social interaction via comments on Facebook became a part of social attraction, which functions as a factor that influencing Facebook usage amongst Facebook users.

Table 2: Distribution of Facebook users by Social Attraction items ( $N=402)$

\begin{tabular}{|c|c|c|c|c|c|c|c|c|}
\hline \multirow{2}{*}{ No. } & \multirow{2}{*}{ Items } & \multicolumn{5}{|c|}{ Percentage (Frequency) } & \multirow{2}{*}{$\mathbf{M}$} & \multirow{2}{*}{ SD } \\
\hline & & 1 & 2 & 3 & 4 & 5 & & \\
\hline 1. & $\begin{array}{l}\text { Based on his/her social interaction } \\
\text { via comments on Facebook, l'd like } \\
\text { to have a friendly chat with } \\
\text { him/her. }\end{array}$ & $\begin{array}{l}1.00 \\
(4)\end{array}$ & $\begin{array}{l}7.96 \\
(32)\end{array}$ & $\begin{array}{l}35.57 \\
(143)\end{array}$ & $\begin{array}{l}27.86 \\
(112)\end{array}$ & $\begin{array}{l}27.61 \\
(111)\end{array}$ & 3.73 & 0.98 \\
\hline 2. & $\begin{array}{l}\text { Based on his/her social interaction } \\
\text { via comments on Facebook, I feel } \\
\text { I know him/her personally. }\end{array}$ & $\begin{array}{l}1.00 \\
(4)\end{array}$ & $\begin{array}{l}18.41 \\
(74)\end{array}$ & $\begin{array}{l}30.60 \\
(123)\end{array}$ & $\begin{array}{l}41.28 \\
(166)\end{array}$ & $\begin{array}{l}8.71 \\
(36)\end{array}$ & 3.38 & 0.92 \\
\hline \multirow[t]{2}{*}{3.} & $\begin{array}{l}\text { Based on his/her social interaction } \\
\text { via comments on Facebook, I } \\
\text { sometimes wish I were more } \\
\text { like him/her. }\end{array}$ & $\begin{array}{l}3.49 \\
(14)\end{array}$ & $\begin{array}{l}19.40 \\
(78)\end{array}$ & $\begin{array}{l}31.84 \\
(128)\end{array}$ & $\begin{array}{l}29.35 \\
(118)\end{array}$ & $\begin{array}{l}15.92 \\
(64)\end{array}$ & 3.35 & 1.07 \\
\hline & & & & & Overal & & 3.49 & 0.99 \\
\hline
\end{tabular}

* Note: 1=Strongly Disagree, 2=Disagree, 3=Neutral, 4=Agree, 5=Strongly Agree

\section{Extraversion}

Based on Table 3, the extraverted users have posted status updates, likes, and shares on Facebook, $39.30 \%$ of the respondents agreed that extraverted user likes meeting and mixing with people $(M=3.91)$. Whereas with the highest mean of extraversion ( $M=4.01), 37.81 \%$ of them strongly agreed that extraverted user often posts positive content on his/her wall. Besides, $35.07 \%$ of the respondents strongly agreed that extraverted user is outgoing and friendly $(M=3.91)$, based on his/her posts on Facebook, e.g., status updates, likes, and shares. This result is tallied with Agarwal (2014) 's discovery that extraverted user is often appraised as assertive, outgoing, amicable, and friendly, that draw inspiration from social situations. This finding also demonstrated that extraversion on Facebook could be determined through status updates, likes, and shares. This statement is as suggested by Marshall et al. (2015) that status updates, likes, and shares are the tools for extraverted users to reflect their interpersonal attraction traits amongst Facebook users.

This finding is similar to the statement that extraverted people spend much time on Facebook (Ong et al. 2011), posting status updates (Wang et al., 2012), upload many photos, and have extraordinarily long lists of online friends (Amichai and Vinitzky, 2010). For instance, Facebook's numerous communication channels such as status updates, wall posts, inbox messages, chat are helpful for individuals looking for some forms of support and for engaging in generalized reciprocity by responding to others' requests (Valenzuela et al. 2014). 
INTERNATIONAL JOURNAL OF ACADEMIC RESEARCH IN BUSINESS AND SOCIAL SCIENCES

Vol. 11, No. 15, Empowering Youth and Community Wellbeing for Sustainable Development, 2021, E-ISSN: 2222-6990 @ 2020 HRMARS

Table 3: Distribution of Facebook users by Extraversion Items ( $N=402)$

\begin{tabular}{|c|c|c|c|c|c|c|c|c|}
\hline \multirow{2}{*}{$\begin{array}{l}\text { No } \\
\text {. }\end{array}$} & \multirow{2}{*}{ Items } & \multicolumn{5}{|c|}{ Percentage (Frequency) } & \multirow{2}{*}{ M } & \multirow{2}{*}{ SD } \\
\hline & & 1 & 2 & 3 & 4 & 5 & & \\
\hline 1. & $\begin{array}{l}\text { Based on his/ her posts on Facebook, } \\
\text { e.g., status updates, likes, and shares, } \\
\text { he/she often post positive content on } \\
\text { his/her wall. }\end{array}$ & $\begin{array}{l}0.00 \\
(0)\end{array}$ & $\begin{array}{l}7.21 \\
(29)\end{array}$ & $\begin{array}{l}22.64 \\
(91)\end{array}$ & $\begin{array}{l}32.34 \\
(130)\end{array}$ & $\begin{array}{l}37.81 \\
(152)\end{array}$ & $\begin{array}{l}4.0 \\
1\end{array}$ & $\begin{array}{l}0.9 \\
5\end{array}$ \\
\hline 2. & $\begin{array}{l}\text { Based on his/ her posts on Facebook, } \\
\text { e.g., status updates, likes, and shares, } \\
\text { he/she likes meeting and mixing with } \\
\text { people. }\end{array}$ & $\begin{array}{l}0.00 \\
(0)\end{array}$ & $\begin{array}{l}12.1 \\
9 \\
(49)\end{array}$ & $\begin{array}{l}16.67 \\
(67)\end{array}$ & $\begin{array}{l}39.30 \\
(158)\end{array}$ & $\begin{array}{l}31.84 \\
(128)\end{array}$ & $\begin{array}{l}3.9 \\
1\end{array}$ & $\begin{array}{l}0.9 \\
8\end{array}$ \\
\hline 3. & $\begin{array}{l}\text { Based on his/ her posts on Facebook, } \\
\text { e.g., status updates, likes, and shares, } \\
\text { he/she is outgoing and friendly. }\end{array}$ & $\begin{array}{l}0.00 \\
(0)\end{array}$ & $\begin{array}{l}8.46 \\
(34)\end{array}$ & $\begin{array}{l}26.87 \\
(108)\end{array}$ & $\begin{array}{l}29.60 \\
(119)\end{array}$ & $\begin{array}{l}35.07 \\
(141)\end{array}$ & $\begin{array}{l}3.9 \\
1\end{array}$ & $\begin{array}{l}0.9 \\
8\end{array}$ \\
\hline & & & & & \multicolumn{2}{|c|}{ Overall } & $\begin{array}{l}3.9 \\
4\end{array}$ & $\begin{array}{l}0.9 \\
7\end{array}$ \\
\hline
\end{tabular}

*Note: 1=Strongly Disagree, 2=Disagree, 3=Neutral, 4=Agree, 5=Strongly Agree

\section{Popularity}

Table 4 illustrates on popular user's number of friends, likes, comments, and shares on Facebook, $25.13 \%$ of the respondents agreed that popular user would go out with certain people just because that people are popular $(M=3.01)$. In comparison, $24.63 \%$ of them agreed that popular user changed the way he/she dress to be more popular $(M=3.16)$. Despite that, $28.36 \%$ of the respondents agreed that popular user had been friends with some people, just because others liked them $(M=3.21)$. Besides that, the highest mean for popularity $(M=3.28)$ stated that popular user exaggerates or makes up information and puts it in his/her own Facebook profile. This breakthrough signified that popular user is always stepping out of the box in order to attract other Facebook users (Robertson, 2003). Popularity on Facebook is clarified based on the number of friends, likes, comments, and shares; as advocated by (Fox and Moreland, 2015), the number of friends, likes, comments, and shares that one had on the network represents the level of user's popularity amongst the culture of a social network, like Facebook. 
INTERNATIONAL JOURNAL OF ACADEMIC RESEARCH IN BUSINESS AND SOCIAL SCIENCES

Vol. 11, No. 15, Empowering Youth and Community Wellbeing for Sustainable Development, 2021, E-ISSN: 2222-6990 @ 2020 HRMARS

Table 4: Distribution of Facebook users by Popularity Items ( $N=402)$

\begin{tabular}{|c|c|c|c|c|c|c|c|c|}
\hline \multirow{2}{*}{ No. } & \multirow{2}{*}{ Items } & \multicolumn{5}{|c|}{ Percentage (Frequency) } & \multirow{2}{*}{ M } & \multirow{2}{*}{ SD } \\
\hline & & 1 & 2 & 3 & 4 & 5 & & \\
\hline 1. & $\begin{array}{l}\text { Based on his/her no. of friends, likes, } \\
\text { comments, and shares on Facebook, } \\
\text { he/she exaggerate or make up } \\
\text { information and put it in his/her } \\
\text { profile. }\end{array}$ & $\begin{array}{l}9.20 \\
(37)\end{array}$ & $\begin{array}{l}6.97 \\
(28)\end{array}$ & $\begin{array}{l}45.77 \\
(184)\end{array}$ & $\begin{array}{l}23.13 \\
(93)\end{array}$ & $\begin{array}{l}14.93 \\
(60)\end{array}$ & 3.28 & 1.09 \\
\hline 2. & $\begin{array}{l}\text { Based on his/her no. of friends, likes, } \\
\text { comments, and shares on Facebook, } \\
\text { he/she has been friends with some } \\
\text { people just because others liked } \\
\text { them. }\end{array}$ & $\begin{array}{l}16.16 \\
(65)\end{array}$ & $\begin{array}{l}8.96 \\
(36)\end{array}$ & $\begin{array}{l}29.60 \\
(119)\end{array}$ & $\begin{array}{l}28.36 \\
(114)\end{array}$ & $\begin{array}{l}16.92 \\
(68)\end{array}$ & 3.21 & 1.29 \\
\hline 3. & $\begin{array}{l}\text { Based on his/her no. of friends, likes, } \\
\text { comments, and shares on Facebook, } \\
\text { he/she changed the way he/she } \\
\text { dress to be more popular. }\end{array}$ & $\begin{array}{l}7.71 \\
(31)\end{array}$ & $\begin{array}{l}24.38 \\
(98)\end{array}$ & $\begin{array}{l}27.86 \\
(112)\end{array}$ & $\begin{array}{l}24.63 \\
(99)\end{array}$ & $\begin{array}{l}15.42 \\
(62)\end{array}$ & 3.16 & 1.18 \\
\hline 4. & $\begin{array}{l}\text { Based on his/her no. of friends, likes, } \\
\text { comments, and shares on Facebook, } \\
\text { he/she would go out with certain } \\
\text { people just because they are } \\
\text { popular. }\end{array}$ & $\begin{array}{l}23.38 \\
(94)\end{array}$ & $\begin{array}{l}9.70 \\
(39)\end{array}$ & $\begin{array}{l}25.62 \\
(103)\end{array}$ & $\begin{array}{l}25.13 \\
(101)\end{array}$ & $\begin{array}{l}16.17 \\
(65)\end{array}$ & 3.01 & 1.39 \\
\hline \multirow[t]{2}{*}{5.} & $\begin{array}{l}\text { Based on his/her no. of friends, likes, } \\
\text { comments, and shares on Facebook, } \\
\text { he/she ignored certain people to be } \\
\text { more popular. }\end{array}$ & $\begin{array}{l}23.38 \\
(94)\end{array}$ & $\begin{array}{l}17.91 \\
(72)\end{array}$ & $\begin{array}{l}20.65 \\
(83)\end{array}$ & $\begin{array}{l}20.65 \\
(83)\end{array}$ & $\begin{array}{l}17.41 \\
(70)\end{array}$ & 2.91 & 1.42 \\
\hline & & & & & Overal & & 3.11 & 1.27 \\
\hline
\end{tabular}

* Note: 1=Strongly Disagree, 2=Disagree, 3=Neutral, 4=Agree, 5=Strongly Agree

The finding shows that some traits of popularity initiate an individual to be attracted to another user, based on popular user's number of friends, likes, comments, and shares. This claim is, as stated by Scott (2014) that the number of friends, photos, and timeline activities influenced the popularity of Facebook profile owners. This condition indicated that network size and their active involvement on Facebook appears to be a reliable indicator of online popularity. Moreover, some of the popular users on Facebook prefers to be acknowledged by having a greater number of friends, likes, comments, and shares on Facebook (Bucher, 2012).

\section{Discussion}

This study concluded that Facebook users shows specific characteristics of physical attraction that sparks for some individuals to be more interested in another person through photos and videos on Facebook, such as the smile, the hairstyle, or the skin colour of the opposite person. The encounter is following Taga (2012) statement that people envision specific characteristics which they understand as beautiful by assessing that person's characteristics, for example, looking at their face or body and making conclusions about the opposite person's physical attraction (Millard, 2009). This 
assessment eventually matters to them to obtain the feeling of happiness that permeated into their everyday lives.

Facebook users are always socially attracted to another person amongst their Facebook friends. This finding is possibly due to the similarity between each other, which makes them believe that they can get along together on Facebook. In agreement with an earlier study, people prefer to interact with others to only whom they feel socially attracted, for the reason that they are more pleasant to be with (Vittengl and Holt, 2000). As a result, based on the social interaction on Facebook, socially attracted people are more likely to communicate with each other (Antheunis et al., 2012).

Facebook users were always attracted to another person who shows the traits of extraversion amongst their Facebook friends. This finding is conceivably due to the traits of high extraversion that someone might find appealing, such as the characteristics of outgoing, talkative, and energetic disposition, which is opposite to introverts who are shy, quiet, and reserved (Eftekhar et al., 2014). Besides, extraverts always seem outstanding, prefer being in the center of attention with a higher number of Facebook friends, and always report engagement in more self-presentation activities such as posting photos, status updates, and shares (Ong et al., 2011).

Facebook users were situated at a moderate level of popularity. The distribution shows that the popularity level amongst Facebook users is quietly even. Some Facebook users are attracted to a person who is popular amongst their Facebook friends, some were not, and this depends on the individual's needs. The needs of certain Facebook users might come from the desire to be in a peaceful mind, despite being in the chaotic of comments, likes, and shares from the popular Facebook users. On the other hand, some of them love to be recognized by having a greater number of friends, likes, comments, and shares on Facebook (Bucher, 2012).

\section{Conclusion}

Popularity has become a trend in self-displaying through SNS; however, Facebook users in this study still do not fully agree with the trend. Nevertheless, other interpersonal attraction traits such as physical attraction, social attraction, and extraversion are still important to improve their interaction network through mediated-communication. All those interpersonal attraction traits facilitate them in maintaining their relationship since they can reduce uncertainty in order to develop trust with each other. This gives implications for interpersonal relationships through computer-mediated communication, and subsequently, social cohesiveness is built in the context of virtual reality. This knowledge contributes to Uncertain Reduction Theory in the axiom of non-verbal and verbal communication as one of the contributors to the reduction of uncertainty. Although a person is interacting through a mediated-communication, anxiety and uncertainty is still exist while they are using Facebook. Therefore, this feeling is acceptable if physical attraction, social attraction, and extraversion are used as a guide in interpersonal communication. 


\section{References}

Agarwal, B. (2014). Personality detection from text: A review. International Journal of Computer System, 1(1), 1-4.

Amichai, H. Y., \& Vinitzky, G. (2010). Social network use and personality. Computers in Human Behaviour, 26(6), 1289-1295.

Andrews, R., Browne, A., Drummond, P., \& Wood, F. (2010). The impact of personality and coping on the development of depressive symptoms in adult burns survivors. Burns, 36(1), 29-37.

Antheunis, M. L., Schouten, A. P., Valkenburg, P. M., \& Peter, J. (2012). Interactive Uncertainty Reduction Strategies and Verbal Affection in Computer-Mediated Communication. Communication Research, 39(6), 757-780.

Attan, S. A. (2011). Relationship between Impression Management Strategies and Social Relationship Dimensions amongst Mardam-Bey's Internet Relay Chat Users (Unpublished Doctoral Dissertation). Universiti Putra Malaysia).

Bailey, R. (2007). Parking Lot Meditations. Xulon Press.

Baumeister, R. F., \& Vohs, K. D. (Eds.). (2007). Encyclopedia of Social Psychology. SAGE.

Barelds, D. P., \& Dijkstra, P. (2009). Positive illusions about a partner's physical attraction and relationship quality. Personal Relationships, 16(2), 263-283.

Blau, P. M. (1964). Exchange and power in social life. John Wiley \& Sons.

Bonson, E., \& Ratkai, M. (2013). A set of metrics to assess stakeholder engagement and social legitimacy on a corporate Facebook page. Online Information Review, 37(5), 787-803.

Bucher, T. (2012). Want to be on the top? Algorithmic power and the threat of invisibility on Facebook. New Media \& Society, 14(7), 1164-1180.

Cabral, J. (2011). Is Generation Y Addicted to Facebook? Journal of Undergraduate Research in Communications, 2(1), 5-14.

Chen, B., \& Marcus, J. (2012). Students' self-presentation on Facebook: An examination of personality and self-construal factors. Computers in Human Behaviour, 28(6), 2091-2099.

Cronbach, L. (1951). Coefficient alpha and the internal structure of tests. Psychometrika, 16, 297-334.

De Vries, L., Gensler, S., \& Leeflang, P. S. (2012). Popularity of brand posts on brand fan pages: An investigation of the effect of social media marketing. Journal of Interactive Marketing, 26(2), 83-91.

Eftekhar, A., Fullwood, C., \& Morris, N. (2014). Capturing personality from Facebook photos and photo-related activities: How much exposure do you need? Computers in Human Behaviour, 37, 162-170.

Ekwok, L. (2017). Facing Criminality on Facebook. People: International Journal of Social Sciences, 3(1), 787-805.

Elmer, E. M., \& Houran, J. (2019). Physical attractiveness in the workplace: Customers do judge books by their covers. Beauty in Business, 14, 1-22.

Eysenck, H. J., \& Eysenck, S. B. (1994). Manual of the Eysenck Personality Questionnaire: (EPQ-R Adult). Educational and Industrial Testing Service.

Forest, A., \& Wood, J. (2012). When social networking is not working individuals with low self-esteem, recognize but do not reap the benefits of self-disclosure on Facebook. Psychological Science, 23(3), 295-302.

Fox, J., \& Moreland, J. J. (2015). The Dark Side of Social Networking Sites: An Exploration of the Relational and Psychological Stressors Associated with Facebook Use and Affordances. Computers in Human Behaviour, 45, 168-176. 
Francis, L., Brown, L., \& Philipchalk, R. (1992). The development of an abbreviated form of the Revised Eysenck Personality Questionnaire (EPQR-A): Its use among students in England, Canada, the USA and Australia. Personality and Individual Differences, 13(4), 443-449.

Gil, L. A., Gil, L. A., Dwivedi, A., Dwivedi, A., Johnson, L. W., \& Johnson, L. W. (2017). Effect of popularity and peer pressure on attitudes toward luxury among teens. Young Consumers, 18(1), 84-93.

Hall, J. A., \& Pennington, N. (2013). Self-monitoring, honesty and cue use on Facebook: The relationship with user extraversion and conscientiousness. Computers in Human Behaviour, 29(4), 1556-1564.

Harris, L., O' Malley, L., \& Patterson, M. (2003). Professional interaction: Exploring the concept of attraction. Marketing Theory, 3(1), 9-36.

Jamerson, M. (2009). Attraction: Why we like the ones we like. Columbia Missourian.

Jin, Yan. (2010). Making Sense Sensibly in Crisis Communication: How Publics' Crisis Appraisals Influence Their Negative Emotions, Coping Strategy Preferences, and Crisis Response Acceptance. Communication Research - COMMUN RES. 37. 522-552. 10.1177/0093650210368256.

Kelley, H. (2013). Personal Relationships: Their Structures and Processes. Psychology Press.

Kleemans, M., Daalmans, S., Carbaat, I., \& Anschütz, D. (2018). Picture perfect: The direct effect of manipulated Instagram photos on body image in adolescent girls. Media Psychology, 21(1), 93110.

Koshy, S. (2013). Factors that affect the use of Facebook and Twitter as marketing tools in the UAE. Proceedings of the UK Academy for Information Systems Conference, UK, 1-7.

Kunnanatt, J. T. (2004). Emotional Intelligence: The New Science of Interpersonal Effectiveness. Human Resource Development Quarterly, 15(4), 489-495.

Makhanova, A., McNulty, J., \& Maner, J. (2017). Relative Physical Position as an ImpressionManagement Strategy: Sex Differences in Its Use and Implications. Psychological Science, 28(5), 567-577.

Mantymaki, M., \& Islam, A. N. (2016). The Janus face of Facebook: Positive and Negative Sides of Social Networking Site Use. Computers in Human Behaviour, 61, 14-26.

Marshall, T. C., Lefringhausen, K., \& Ferenczi, N. (2015). The Big Five, self-esteem, and narcissism as predictors of the topics people write about in Facebook status updates. Personality and Individual Differences, 85, 35-40.

McCroskey, J. C., \& McCain, T. A. (1974). The Measurement of Interpersonal Attraction. Speech Monographs, 41, 261-266.

McCroskey, L. L., McCroskey, J. C., \& Richmond, V. P. (2006). Analysis and Improvement of the Measurement of interpersonal attraction and Homophily. Communication Quarterly, 54(1), 131.

Mendelson, A., \& Papacharissi, Z. (2010). Look at us: Collective narcissism in college student Facebook photo galleries. The Networked Self: Identity, Community and Culture on Social Network Sites, 1974, 1-37.

Millard, J. (2009). Performing Beauty: Dove's “Real Beauty" Campaign. Symbolic Interaction, 32(2), 146168.

Mohammadi, E., Gregory, K. B., Thelwall, M., \& Barahmand, N. (2020). Which health and biomedical topics generate the most Facebook interest and the strongest citation relationships?. Information Processing \& Management, 57(3), 1-29. 
Montoya, R. M., Horton, R. S., \& Kirchner, J. (2008). Is actual similarity necessary for attraction? A meta-analysis of actual and perceived similarity. Journal of Social and Personal Relationships, 25(6), 889-922.

Moore, K., \& McElroy, J. C. (2012). The influence of personality on Facebook usage, wall postings and regret. Computers in Human Behaviour, 28(1), 267-274.

Naragon-Gainey, K., Watson, D., \& Markon, K. E. (2009). Differential Relations of Depression and Social Anxiety Symptoms to the Facets of Extraversion/Positive Emotionality. Journal of Abnormal Psychology, 118(2), 299-310.

Ong, E. Y., Ang, R. P., Ho, J. C., Lim, J. C., Goh, D. H., Lee, C. S., \& Chua, A. Y. (2011). Narcissism, extraversion and adolescents' self-presentation on Facebook. Personality And Individual Differences, 50(2), 180-185.

Papadopoulos, F., Kitsak, M., Serrano, M. Á., Boguná, M., \& Krioukov, D. (2012). Popularity versus similarity in growing networks. Nature, 489(7417), 537-540.

Pempek, T., Yermolayeva, Y., \& Calvert, S. (2009). College students' social networking experiences on Facebook. Journal of Applied Developmental Psychology, 30(3), 227-238.

Rawlings, B., Flynn, E., \& Kendal, R. (2017). To Copy or To Innovate? The Role of Personality and Social Networks in Children's Learning Strategies. Child Development Perspectives, 11(1), 39-44.

Robertson, J. W. (2003). Stepping out of the box: Rethinking the failure of ICT to transform schools. Journal of Educational Change, 4(4), 323-344.

Simoncic, T. E., Kuhlman, K. R., Vargas, I., Houchins, S., \& Lopez-Duran, N. L. (2014). Facebook use and depressive symptomatology: Investigating the role of neuroticism and extraversion in youth. Computers in Human Behaviour, 40, 1-5.

Simpson, J., \& Harris B. (1994). Perspectives on close relationships. In L. Ann., \& H. John. (Eds.), Interpersonal attraction (11 $1^{\text {th }}$ ed., pp.45-66). Allyn \& Bacon.

Taga, C. (2012). Maybe She's Born with It: Analyzing theories of Beauty from Biology, Society and the Media. Regis University.

Unal-Colak, F., \& Kobak-Uzun, K. (2011). Determining interpersonal attraction in educational environment and the relation with motivation. International Journal on New Trends in Education and Their Implications, 2(1), 47-56.

Utz, S., Tanis, M. A., \& Vermeulen, I. E. (2012). It is all about being popular: The effect of need for popularity on social network site use.Cyberpsychology, Behaviour and Social Networking, 15(1), 37-42.

Valenzuela, S., Halpern, D., \& Katz, J. E. (2014). Social network sites, marriage well-being and divorce: Survey and state-level evidence from the United States. Computers in Human Behaviour, 36, 94-101.

Vittengl, J. R., \& Holt, C. S. (2000). Getting acquainted: The relationship of self-disclosure and social attraction to positive affect. Journal of Social and Personal Relationships, 17(1), 53-66.

Wang, J. L., Jackson, L. A., Zhang, D. J., \& Su, Z. Q. (2012). The relationships among the Big Five Personality factors, self-esteem, narcissism, and sensation-seeking to Chinese University students' uses of Social Networking Sites (SNSs). Computers in Human Behaviour, 28(6), 23132319.

Weijs, C., Majowicz, S., Coe, J. B., Desmarais, S., \& Jones-Bitton, A. (2017). The personal use of Facebook by public health professionals in Canada: Implications for public health practice. Journal of Communication in Healthcare, 10(1), 8-15. 
INTERNATIONAL JOURNAL OF ACADEMIC RESEARCH IN BUSINESS AND SOCIAL SCIENCES

Vol. 11, No. 15, Empowering Youth and Community Wellbeing for Sustainable Development, 2021, E-ISSN: 2222-6990 @ 2020 HRMARS

Zywica, J., \& Danowski, J. (2008). The faces of Facebookers: Investigating social enhancement and social compensation hypotheses; predicting Facebook ${ }^{\mathrm{TM}}$ and offline popularity from sociability and self-esteem and mapping the meanings of popularity with semantic networks. Journal of Computer-Mediated Communication, 14(1), 1-34. 